http://www.pakjas.com.pk

\title{
POTENTIAL PATHOGENIC YEASTS ISOLATED FROM FRESH DATE FRUITS (RUTAB)
}

\author{
Fahad M. Aljasass ${ }^{1, *}$, Salah M. Aleid ${ }^{2,3}$ and Siddig H. Hamad ${ }^{2}$ \\ ${ }^{1}$ King Abdulaziz City for Science and Technology, Life science and Environment Research Institute, National Center \\ for Agricultural Technology, P.O. Box 6086, Riyadh 11442, Saudi Arabia; ${ }^{2}$ College of Agricultural and Food Sciences, \\ King Faisal University, P.O. Box 400, Hofuf 31982, Saudi Arabia; ${ }^{3}$ Date Palm Research Center of Excellence, King \\ Faisal University, P.O. Box 400, Hofuf 31982, Saudi Arabia. \\ "Corresponding author's e-mail: aljasass@ kacst.edu.sa
}

\begin{abstract}
Fifty samples of fresh date fruits showing signs of microbial spoilage were collected from Hofuf City markets in Saudi Arabia. Yeasts involved in spoilage were counted by inoculation on PDA plates and incubation at $25^{\circ} \mathrm{C}$ for $2-3$ days, and then isolates of the dominant strains were identified. Potentially pathogenic yeasts were involved in the spoilage of six out of the 50 samples tested (12\%). The yeast counts in these samples were in the range $10^{4}$ to $10^{7} \mathrm{CFU} / \mathrm{g}$. The pathogenic yeasts constituted 12 to $100 \%$ of these counts, i.e. some samples were spoiled by the pathogenic yeasts only. The dominant pathogen was Candida tropicalis found in three of the six spoiled samples representing 12, 75 and $100 \%$ of the yeast population involved in spoilage. C. krusei, Issatchenkia orientalis and C. albicans were each found in one sample making 14.7, 17 and $25.3 \%$ of the yeast population detected in the spoiled samples, respectively.
\end{abstract}

Keywords: Date fruits, spoilage microflora, pathogenic yeasts, candidiasis

\section{INTRODUCTION}

Date palms (Phoenix dactylifera L.) are by far the most important food crop produced in the Kingdom of Saudi Arabia. The country is ranked as the second largest producer of date fruits in the world with $\mathbf{1 , 1 2 2 , 8 2 0}$ metric tons annual production (FAO, 2016). The fruit becomes ripe and edible in two stages, namely the Rutab and the Tamr stages. Rutab contains 35 to $40 \%$ moisture and 45 to $48 \%$ sugars (dry matter basis) while Tamr contains 10 to $15 \%$ moisture and 60 to $88 \%$ sugars (dry matter basis) (Barreveld, 1993). Hence Tamr is generally regarded as stable while Rutab is highly susceptible to microbial spoilage. Studies on the microbiological contamination and spoilage of date fruits are limited. Reports on microbial contamination of Tamr describe aerobic mesophilic bacteria, yeasts, molds, coliforms, Staphylococcus aureus, Aspergillus flavus and lactic acid bacteria as the main contaminants (Bolin et al., 1972; Abu-Zinada and Ali, 1982; El-Sherbeeny et al., 1985; Nussinovitch et al., 1989; Aidoo et al., 1996; Shenasi et al., 2002). Little work is done on the microbial spoilage of date fruits, which is mainly caused by molds, yeasts and lactic acid bacteria (Hamad, 2012; Hamad, 2008; Kader, 2007).

Though yeasts are described as important spoilage agents of date Rutab, no reports about pathogenic yeasts associated with this fruit are found in the literature cited. Candidiasis, caused by yeasts, usually occurs in persons with impaired immune response or when the normal body microflora is suppressed (e.g. by antibiotics). The disease affects mucosa, outer skin and sometimes inner organs of the human body such as the mouth and vagina (Kayser et al., 2005; Singleton and Sainsbury, 1997). Candida albicans infects human bodies, especially the skin and the gastrointestinal and genitourinary tracts, causing the majority of Candida bloodstream infections (candidemia) (Pfaller et al., 2006). Candida krusei is related to diarrhea in young children and occasionally to systemic diseases. It is reported to colonize gastrointestinal, respiratory and urinary tracts of humans (Rippon, 1988), and was also isolated from foods like beer, milk products, pickle brine, and from skins and feces of animals and birds (Kreger-Va, 1984).

This study was carried out to investigate the presence of potential pathogenic yeasts among the spoilage microflora of date fruits at the Rutab stage.

\section{MATERIALS AND METHODS}

Samples collection: Fifty fresh date fruit (Rutab stage) samples from different varieties showing signs of microbial spoilage were collected in sterile bottles from 10 outlets in Hofuf City markets in Saudi Arabia. The samples were transported within one hour to the laboratory and analyzed for microbiological content on the same day.

Microbiological analysis: Samples of Rutab (10 g) were weighed into sterile stomacher bags, $90 \mathrm{ml}$ sterile peptone water (CM0009, Oxoid, Basingstoke, UK) added and homogenized in a stomacher (Lab-Blender 400, Seward Medical, Worthington, UK) for 45 second. Aliquots (1.0 or 
$0.1 \mathrm{ml}$ ) were plated in duplicate as 10 -fold dilutions in peptone water. Yeasts were grown on potato dextrose agar plates (PDA; CM0139, Oxoid) at $30^{\circ} \mathrm{C}$ for 3 days, and molds on PDA plates at 20 to $30^{\circ} \mathrm{C}$ in 3 to 7 days. Lactic acid bacteria (LAB) were enumerated on deMan Rogosa Sharpe agar for lactobacilli (CM0361, Oxoid) and on M17 agar for streptococci and lactococci (CM0785, Oxoid). The plates were incubated in anaerobic jars with anaerobic gas generating kits (BR0038, Oxoid) for 2 to 3 days at $30^{\circ} \mathrm{C}$. For identification of yeasts, colonies of different forms were counted, and then 5 isolates were made from each colony form. The isolates were finally purified by successive streaking on PDA plates and the pure cultures kept in the refrigerator $\left(4 \pm 1^{\circ} \mathrm{C}\right)$ in PDA test tubes for identification.

Identification of yeasts: The yeast isolates (30 isolates) were identified according to Barnett et al. (2000). First, microscopic examination of the appearance of nonfilamentous vegetative cells grown in shake flasks in malt extract broth (CM0057) for 2 days at $25^{\circ} \mathrm{C}$, and microscopic examination for filamentous growth using the slide culture technique was performed. The isolates were then examined for glucose fermentation in Durham tubes and for sporulation on; malt-yeast-glucose-peptone (YM agar), Gorodkowa agar, McClary acetate agar, Malt extract agar. The plates incubated at $25^{\circ} \mathrm{C}$ and examined after 3 days for up to 6 weeks. After that, the appropriate subsequent tests according to Barnett identification keys 1, 2, 3, and 4 (among 14 fermentation, 47 aerobic growth (auxanograms), 10 nitrogen source, 10 vitamin requirement, 7 growth temperature, 2 cycloheximide concentration, urea hydrolysis, $2 \mathrm{NaCl}$ concentration and 2 glucose concentration tests) were performed (all chemicals used were from Sigma). Using the results of the above mentioned tests, the isolates were then identified according to Barnett identification keys.

\section{RESULTS}

Potential pathogenic yeasts were found in 6 out of 50 spoiled tested Rutab samples (Table 1), representing 12\% of total samples. In sample 4 , the yeast population involved in spoilage was $2.4 \times 10^{5} \mathrm{CFU} / \mathrm{g}$, of which the potential pathogenic yeasts formed about $75 \%\left(1.8 \times 10^{5} \mathrm{CFU} / \mathrm{g}\right)$. Molds at a load of $8.8 \times 10^{5} \mathrm{CFU} / \mathrm{g}$ were also involved in the spoilage of this sample. Since the microbial load causing food spoilage is about $10^{6}$ cells/g.ml.cm² (Ray, 2004), this sample can be regarded as spoiled. The relatively high load of the potential pathogenic yeasts $\left(1.8 \times 10^{5} \mathrm{CFU} / \mathrm{g}\right)$ indicates their substantial involvement in sample spoilage. Sample 14 was spoiled by mixed population of lactic acid bacteria at a load of $4.2 \times 10^{5}$ $\mathrm{CFU} / \mathrm{g}$, and yeasts at $3.8 \times 10^{6} \mathrm{CFU} / \mathrm{g}$ (Table 1). The load of the pathogenic yeasts was $9.6 \times 10^{5} \mathrm{CFU} / \mathrm{g}$ making about $25.3 \%$ of the total yeast load. This is a relatively high load and indicates that these pathogenic yeasts significantly contributed to the spoilage of the sample. The spoilage of sample 17 was caused by molds at a load of $5.7 \times 10^{5} \mathrm{CFU} / \mathrm{g}$ and yeasts at $4.7 \times 10^{5} \mathrm{CFU} / \mathrm{g}$. The pathogenic yeasts constituted about $17.0 \%$ of the yeast population with a load of $8.0 \times 10^{4} \mathrm{CFU} / \mathrm{g}$, which is a relatively low load indicating that the contribution of the pathogenic yeasts to the spoilage of the sample was relatively weak. Sample 20 was spoiled by yeasts only, with a load of $6.2 \times 10^{7} \mathrm{CFU} / \mathrm{g}$. The pathogenic yeasts represented about $12 \%$ of the spoilage yeasts population with a load of $7.5 \times 10^{6} \mathrm{CFU} / \mathrm{g}$, meaning that they significantly contribute to the sample spoilage. Sample 41 was alse spoiled by yeasts only, with a load of $5.3 \times 10^{6} \mathrm{CFU} / \mathrm{g}$ for total yeast count and $7.8 \times 10^{5} \mathrm{CFU} / \mathrm{g}$ for the potential pathogenic yeasts. The pathogenic yeasts made about $14.7 \%$ of the total yeast population, indicating their moderate contribution to the sample spoilage. The spoilage of sample 48 was caused by a mixed population of molds and lactic acid bacteria at loads of $2.6 \times 10^{5}$ and $5.6 \times 10^{6} \mathrm{CFU} / \mathrm{g}$, respectively, and yeasts at $8.3 \times 10^{4} \mathrm{CFU} / \mathrm{g}$. All yeast strains were pathogenic with their low count designates there relative weak contribution.

Table 1. Presence of pathogenic yeasts together with other spoilage microbes in 6 of the 50 spoiled Rutab fruit samples.

\begin{tabular}{lccccc}
\hline \multirow{2}{*}{$\begin{array}{l}\text { Sample } \\
\text { No. }\end{array}$} & $\begin{array}{c}\text { Total } \\
\text { yeasts }\end{array}$ & $\begin{array}{c}\text { Patho- } \\
\text { genic } \\
\text { yeasts }\end{array}$ & $\begin{array}{c}\text { \% } \\
\text { pathogen } \\
\text { ic yeasts }\end{array}$ & $\begin{array}{c}\text { Lactic } \\
\text { acid } \\
\text { bacteria }\end{array}$ & Molds \\
\hline 4 & $2.4 \times 10^{5}$ & $1.8 \times 10^{5}$ & $75 \%$ & n.d. & $8.8 \times 10^{5}$ \\
14 & $3.8 \times 10^{6}$ & $9.6 \times 10^{5}$ & $25.3 \%$ & $4.2 \times 10^{5}$ & n.d. \\
17 & $4.7 \times 10^{5}$ & $8.0 \times 10^{4}$ & $17.0 \%$ & n.d. & $5.7 \times 10^{5}$ \\
20 & $6.2 \times 10^{7}$ & $7.5 \times 10^{6}$ & $12.0 \%$ & n.d. & n.d. \\
41 & $5.3 \times 10^{6}$ & $7.8 \times 10^{5}$ & $14.7 \%$ & n.d. & n.d. \\
48 & $8.3 \times 10^{4}$ & $8.3 \times 10^{4}$ & $100 \%$ & $5.6 \times 10^{6}$ & $2.6 \times 10^{5}$ \\
\hline
\end{tabular}

Identification of yeast isolates: Thirty yeast isolates were obtained from six spoiled date fruit samples in the Rutab stage (5 isolates from each sample, showing identical colony form) were identified according to Barnett et al. (2000) using morphological and physiological tests. The 5 isolates from each sample were found to represent one yeast strain with identical biochemical profiles. The isolates from samples 4 , 20 and 48 (isolates 4, 20 and 48, Tables 2 and 3) were identified as Candida tropicalis. They represented three different strains as shown by differences in their biochemical profiles (Table 3). The isolates from samples 14, 17, and 41 (isolates 14, 17 and 41, Tables 2, 3) were identified as Candida albicans, Issatchenkia orientalis and Candida krusei (asexual state of I. orientalis, Barnett et al. 2000), respectively. All of these yeast strains were osmotolerant showing growth at 50 and $60 \%$ glucose concentration (Table 3 ), and were sufficiently thermotolerant growing at temperatures up to $45^{\circ} \mathrm{C}$ (results not shown). They are therefore well adapted to growth on date fruits with their high sugar content and in the hot environment of the Kingdom of 
Table 2. Morphological characteristics of yeasts isolated from spoiled Rutab samples.

\begin{tabular}{|c|c|c|c|c|}
\hline \multirow[t]{2}{*}{ Yeast isolates } & \multicolumn{4}{|c|}{ Morphological characteristics } \\
\hline & Colony & Vegetative cells & Filaments & Sexual reproduction \\
\hline $\begin{array}{l}\text { Isolates } 4 \\
\text { Identified as } C \text {. tropicalis }\end{array}$ & $\begin{array}{c}\text { Butyrous and cream in } \\
\text { color }\end{array}$ & $\begin{array}{c}\text { Budding, } \\
\text { pseudohyphae }\end{array}$ & $+^{\mathrm{a}}$ & $-b$ \\
\hline $\begin{array}{l}\text { Isolates } 14 \\
\text { Identified as } C \text {. albicans }\end{array}$ & $\begin{array}{l}\text { Butyrous and white in } \\
\text { color }\end{array}$ & Budding & - & - \\
\hline $\begin{array}{l}\text { Isolates } 17 \text { Identified as } \\
\text { Issatchenkia orientalis }\end{array}$ & $\begin{array}{l}\text { Butyrous and white in } \\
\text { color }\end{array}$ & $\begin{array}{l}\text { Budding, } \\
\text { pseudohyphae }\end{array}$ & + & $\begin{array}{l}2 \text { to } 3 \text { round } \\
\text { ascospores }\end{array}$ \\
\hline $\begin{array}{l}\text { Isolates } 20 \\
\text { Identified as } C \text {. tropicalis }\end{array}$ & $\begin{array}{l}\text { Butyrous and cream in } \\
\text { color }\end{array}$ & $\begin{array}{c}\text { Budding, septate } \\
\text { hyphae }\end{array}$ & + & - \\
\hline $\begin{array}{l}\text { Isolates } 41 \\
\text { Identified as C. krusei }\end{array}$ & $\begin{array}{l}\text { Butyrous and cream in } \\
\text { color }\end{array}$ & $\begin{array}{l}\text { Budding, long } \\
\text { chains }\end{array}$ & - & - \\
\hline $\begin{array}{l}\text { Isolates } 48 \\
\text { Identified as C. tropicalis }\end{array}$ & $\begin{array}{l}\text { Butyrous and cream in } \\
\text { color }\end{array}$ & $\begin{array}{l}\text { Budding, } \\
\text { pseudohyphae }\end{array}$ & + & - \\
\hline
\end{tabular}

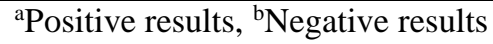

Table 3. Biochemical profiles of the isolates (all of them ferment glucose) compared to relevant yeasts.

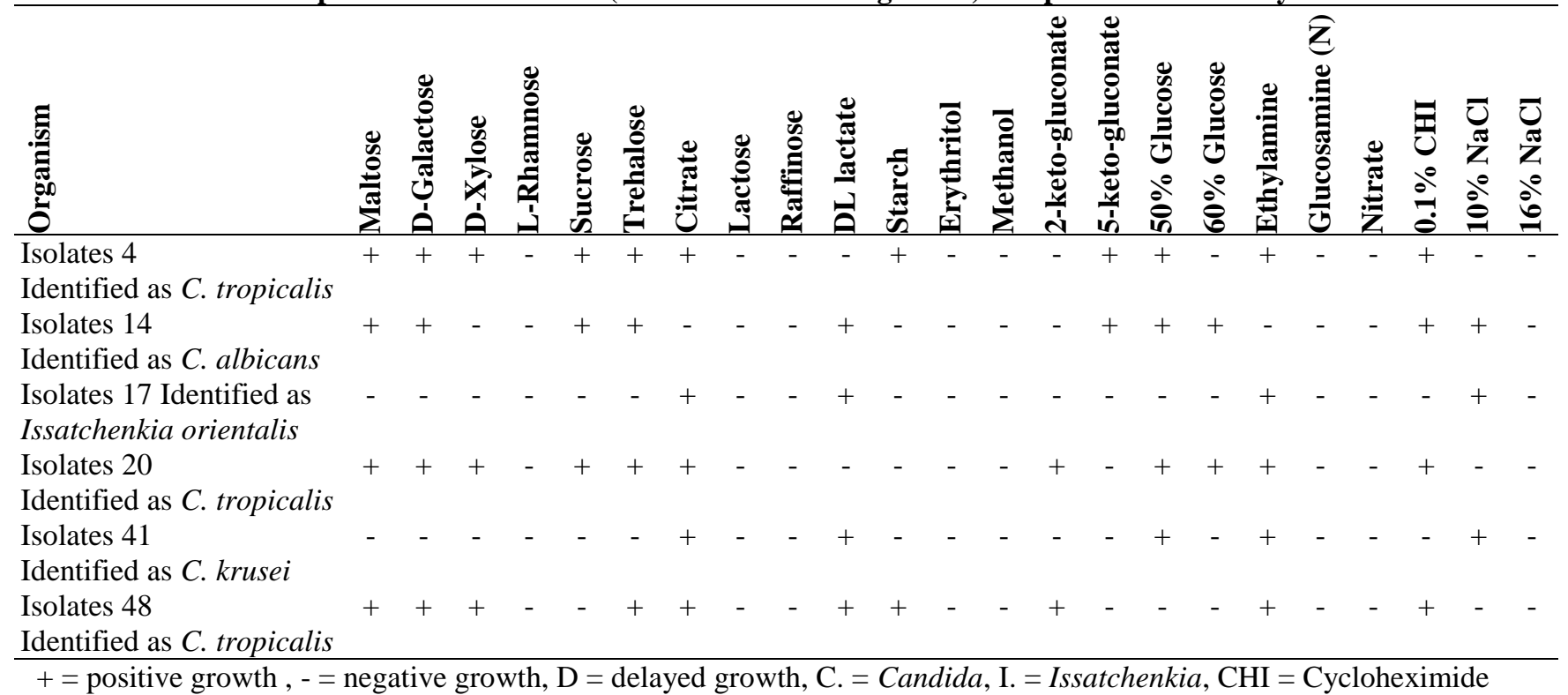

Saudi Arabia. Furthermore, all of these yeast species are described as pathogenic causing different forms of candidiasis (Bourgeois et al., 2010; Kothavade et al., 2010; Kayser et al., 2005; Kockova-Kratochvilova, 1990). Candidiasis usually occurs in persons with impaired immune response or when the normal body microflora is suppressed (e.g. by antibiotics). The disease affects mucosa, outer skin and sometimes inner organs of the human body such as the mouth, vagina etc. (Kayser et al., 2005; Singleton and Sainsbury, 1997).

Potential pathogenic yeasts were isolated from 6 out of 50 spoiled Rutab samples. They represent 12 to $100 \%$ of the detected yeast population in the samples and contributed in varying degrees to their spoilage. The dominant pathogen was Candida tropicalis found in three of six spoiled samples. $C$. albicans, Issatchenkia orientalis and its asexual state $C$. krusei were both found in one sample. All of these yeast strains were thermotolerant and osmotolerant, hence well adapted to growth on dates and in the hot environment of the Kingdom of Saudi Arabia. It could, therefore, be said that these potential pathogens are spreading widely in date fruits initiating a significant human health hazard. Development of rutab fruits handling processes capable in reducing the extent of contamination with these pathogenic yeasts is urgently needed. According to the Saudi

\section{DISCUSSION}

specifications for microbial levels in foods, no more than 10 to 100 yeast cells/g should be detected in 2 out of 5 replicates tested for a sample of dates (SASO, 1999). Aleid 
et al. (2012) evaluated the utilization of modified atmosphere packaging to extend the shelf life of Khalas fresh dates. They observed that the washed khalal samples exhibited low yeast and mold counts $(<10 \mathrm{CFU} / \mathrm{g})$. Special care should be taken during harvest which occurs in the windy dry season in Saudi Arabia. Moreover, preventive measures should be implemented in traditional fresh dates markets in Saudi Arabia to overcome poor hygienic conditions.

Candida tropicalis and Issatchenkia orientalis were isolated from wine and Korean grape wine pomace (Seo et al., 2007). One of the characteristics of these microbes is acid and ethanol tolerance (Okuma et al., 1986; Kim et al., 2008). According to Basu et al. (2011) Candida tropicalis was isolated from blood and urine of patients admitted to intensive care units of different hospitals. Candida albicans is a constituent of human flora, coexisting on skin and the gastrointestinal and genitourinary tracts, causing the majority of Candida bloodstream infections (candidemia) (Pfaller et al., 2006). Candida krusei is related to diarrhea in young children and occasionally associated with systemic disease. Also, it is reported to be colonizing gastrointestinal, respiratory and urinary tracts in patients (Rippon, 1988.). Candida krusei was isolated from foods like beer, milk products and pickle brine as well as from skins and feces of animals and birds (Kreger-Va, 1984). Issatchenkia orientalis was isolated from camel's milk (Rezki et al., 2013). Some date fruit varieties contain antimicrobial components such as tannins which can inhibit the growth of many fungi and bacteria strains on fruits (Nelson et al., 1997; Ishida et al., 2006).

Conclusion: Potential pathogenic yeasts are widely spread in harvested date fruits in Saudi Arabia, hence presenting a significant health hazard. They also contribute to spoilage of date fruit and may represents up to $100 \%$ of the yeast population involved in spoilage. The dominant pathogen is Candida tropicalis followed by C. albicans, Issatchenkia orientalis and its asexual state $C$. krusei. These yeasts cause varying forms of illness to humans. Improved Rutab fruits handling methods that help in reducing the extent of contamination with these pathogenic yeasts is urgently needed.

Acknowledgement: The authors would like to thank King Abdul Aziz City for Science and Technology for the financial support of this work under grant number ARP-27-96.

\section{REFERENCES}

Abu-Zinada, A.H and M.I. Ali. 1982. Fungi associated with dates in Saudi Arabia. J. Food Prot. 45:842-844.

Aidoo, K.E., R.F. Tester, J.E. Morrison and D. MacFarlane. 1996. The composition and microbial quality of pre- packed dates purchased in Greater Glasgow. Int. J. Food Sci. Technol. 31:433-438.

Aleid, S.M., A.R. Barber, M. Rettke, N. Leo, W.A. Alsenaien and A.A. Sallam. 2012. Utilization of modified atmosphere packaging to extend the shelf Life of Khalas fresh dates. Int. J. Food Sci. Technol. 47:1518-1525.

Barnett, J.A., R.W. Payne and D. Yarrow. 2000. Yeasts: characteristics and identification, $3^{\text {rd }}$ Ed. Cambridge University Press, Cambridge, United Kingdom.

Barreveld, W.H. 1993. Date palm production. FAO Agricultural Services Bulletin 101. Food and Agriculture Organization, Rome.

Basu, S., D. Chakraborty, S.K. Dey and S. Das. 2011. Biological characteristics of nosocomial Candida tropicalis isolated from different clinical materials of critically ill patients at ICU. Int. J. Microbiol. Res. 2:112119.

Bolin, H.R., A.D. King, W.L. Stanely and L. Jurd. 1972. Antimicrobial protection of moisturized Deglet Noor dates. Appl. Microbiol. 4:799-802.

Bourgeois, N., L. Dehandschoewercker, S. Bertout, P.J. Bousquet, P. Rispail and L. Lachaud. 2010. Antifungal susceptibility of 205 Candida spp. Isolated primarily during invasive candidiasis and comparison of the Vitek 2 system with the CLSI broth microdilution and Etest methods. J. Clinical Microbiol. 48:154-161.

El-Sherbeeny, M.R., M.F. Saddik and F.L. Bryan. 1985. Microbial profiles of foods served by street vendors in Egypt. Int. J. Food Microbiol. 2:355-364.

FAO. 2016. FAOSTAT. Statistics Division, Food and Agriculture Organization. Available online at http:// http://www.fao.org/statistics/en

Hamad, S.H. 2008. Microbial spoilage of date Rutab collected from the markets of Al-Hofuf City in the Kingdom of Saudi Arabia. J. Food Prot. 71:1406-1411.

Hamad, S.H. 2012. The microbial quality of processed date fruits collected from a factory in Al-Hofuf City. Emir. J. Food Agric. 24:105-112.

Ishida, K., J.C.P. de Mello, D.A.G. Cortez, B.P.D. Filho, T. Ueda-Nakamura and C.V. Nakamura. 2006. Influence of tannins from Stryphnodendron adstringens on growth and virulence factors of Candida albicans. J. Antimicrob. Chemother. 58:942-949.

Kader, A.A. 2007. Recommendations for maintaining postharvest quality. Department of Plant Science, University of California, Davis. Available online at http://postharvest.ucdavis.edu/ProduceFacts/Fruit/Dates. html

Kim, D.H., Y.A. Hong and H.D. Park. 2008. Co-fermentation of grape must by Issatchenkia orientalis and Saccharomyces cerevisiae reduces the malic acid content. Biotechno. Lett. 30:1633-1638. 
Kayser, F.H., K.A. Bienz, J. Eckert and R.M. Zinkernagel. 2005. Medical microbiology. Thieme, Stuttgart, New York.

Kockova-Kratochvilova, A. 1990. Yeasts and yeast-like organisms. VCH Verlagsgesellschaft, Weinheim, Germany.

Kothavade, R.J., M.M. Kura, A.G. Valand and M.H. Panthaki. 2010. Candida tropicalis: its prevalence, pathogenicity and increasing resistance to fluconazole. J. Medical Microbiol. 59:873-880.

Kreger-Van Rij, N.J.W. 1984. The Yeasts: a taxonomic study, $3^{\text {rd }}$ Ed. Elsevier Science Publishers B.V., Amsterdam, The Netherlands.

Nelson, K.E., A.N. Pell, P.H. Doane, B.I. Giner-Chavez and P. Schofield. 1997. Chemical and biological assays to evaluate bacterial inhibition by tannins. J. Chem. Ecol. 23:1175-1194.

Nussinovitch, A., B. Rosen, H. Salik and I.J. Kopelman. 1989. Effect of heating media on the microbiology and shelf life of heat pasteurized soft dates. Lebensm. Wiss. Technol. 22:245-247.

Okuma, Y., A. Endo, H. Iwasaki, Y. Ito and S. Goto. 1986. Isolation and properties of ethanol-using yeasts with acid and ethanol tolerance. J. Ferment. Technol. 64:379-382.

Pfaller, M.A., D.J. Diekema, A.L. Colombo, C. Kibbler, K.P. $\mathrm{Ng}$, D.L. Gibbs and V.A. Newell. 2006. Candida rugosa, an emerging fungal pathogen with resistance to azoles. J. Clinical Microbiol. 44:3578-358.

Rezki, M.A., L. Benbadis, G. DeBillerbeck, Z. Benbayer and J.M. François. 2013. Isolation and physiological characterization of indigenous yeasts from some Algerian agricultural and dairy products. J. Yeast Fungal Res. 4:75-83.

Rippon, J.W. 1988. Medical Mycology, $3^{\text {rd }}$ Ed. W.B. Saunders Co., Philadelphia, USA.

Saudi Standards, Metrology and Quality Organization (SASO). 1999. Microbiological limits for food materials, pp. 1556; Kingdom of Saudi Arabia.

Seo, S.H., C.H. Rhee and H.D. Park. 2007. Degradation of malic acid by Issatchenkia orientalis KMBL 5774, an acidophilic yeast strain isolated from Korean grape wine pomace. J. Microbiol. 45:521-527.

Shenasi, M., K.E. Aidoo and A.A. Candlish. 2002. Microflora of date fruits and production of aflatoxins at various stages of maturation. Int. J. Food Microbiol. 79:113-119.

Singleton, P. and D. Sainsbury. 1997. Dictionary of microbiology and molecular biology, $2^{\text {nd }}$ Ed. John Wiley and Sons. Chichister. New York, Brisbane, Toronto, Singapore. 